Original Research Article

\title{
Evaluation of antihyperglycemic activities of Bangladeshi medicinal plant Cinnamomum tamala Leaf extracts in alloxan treated Albino Rats
}

\author{
Abu Zaffar Shibly*, Laila Arjumand Suborna, Juthi Adhikari, Md. Shariful Islam
}

\begin{abstract}
Department of Biotechnology and Genetic Engineering, Mawlana Bhashani Science and Technology University, Santosh, Tangail 1902, Bangladesh
\end{abstract}

Received: 07 November 2017 Accepted: 28 November 2017

*Correspondence to: Abu Zaffar Shibly, Email: zaffarshibly1987@ gmail.com

Copyright: (C) the author(s), publisher and licensee Medip Academy. This is an openaccess article distributed under the terms of the Creative Commons Attribution NonCommercial License, which permits unrestricted noncommercial use, distribution, and reproduction in any medium, provided the original work is properly cited.

\begin{abstract}
Background: Diabetic mellitus is a multifactorial disorder associated with its devastating consequences has assumed epidemic proportion in Bangladesh.

Methods: The study evaluates the anti-hyperglycemic activity of the aqueous extracts of $C$. tamala (CTLEt) leaves in blood glucose of albino rats. Type II diabetes mellitus was induced by injecting alloxan at the concentration of $100 \mathrm{mg} / \mathrm{kg}$ body weight in male albino rats. The diabetic rats were administered orally with aqueous CTLEt at the amount of $1.0 \mathrm{ml}, 1.5 \mathrm{ml}$ and $2.0 \mathrm{ml}$ with lab diet and glibenclamide $(5 \mathrm{mg} / \mathrm{kg}$ of body weight). Then blood glucose levels were estimated in all groups after 2 hours, 4 hours, 6 hours, 12 hours and 18 hours of the treatment with CTLEt and a known antidiabetic drug glibenclamide.

Results: A comparison was made between the action of CTLEt and glibenclamide. Blood glucose levels of the CTLEt on $18^{\text {th }}$ hours of the study were 8.6 to $5.1 \mathrm{mmol} / \mathrm{L}$ ( $1 \mathrm{ml} \mathrm{CTLEt} \mathrm{with} \mathrm{lab} \mathrm{diet),} 10.4$ to $4.9 \mathrm{mmol} / \mathrm{L}$ ( $1.5 \mathrm{ml} \mathrm{CTLEt}$ with lab diet), 14.7 to $4.3 \mathrm{mmol} / \mathrm{L}$ (2.0ml CTLEt with lab diet) in comparison of diabetic control $(9.5$ to $8.5,8.7$ to $7.8,7.7$ to $7.1 \mathrm{mmol} / \mathrm{L})$ and glibenclamide (13.9 to $6.5,16.3$ to $6.1,9.5$ to $5.1 \mathrm{mmol} / \mathrm{L})$. Among the sample level, the $2.0 \mathrm{ml} \mathrm{CTLEt}$ showed a higher efficiency of hypoglycemic effect on alloxan induced diabetic rats.

Conclusions: Till date, there is no specific experimental work in Bangladesh about the evolution of antidiabetic activity of $C$. tamala plant in animal model. Further studies should be undertaken to find out the molecular mechanism of the leaf powder of $C$. tamala medicinal plant.
\end{abstract}

Keywords: Alloxan, Anti-hyperglycemic activity, Cinnamomum tamala

\section{INTRODUCTION}

Diabetes is a global public health problem associated with devastating consequences and has assumed epidemic proportion in developing countries of the world. ${ }^{1}$ Diabetes mellitus is known as a non-communicable diseases resulting by decreased in insulin secretion, and impaired insulin action. ${ }^{2} C$. tamala is known as evergreen tropical tree, belonging to the Lauraceae family which is mainly used as flavoring agents in foods and is widely used in pharmaceutical preparations because of its hypoglycemic, stimulant and carminative properties. It grows throughout Bangladesh but is cultivated more in southern regions as a spice as well as for its medicinal value. ${ }^{3}$ The leaves are carminative, stimulant, diuretic, diaphoretic, lactagogue, deobstruent and aromatic. ${ }^{4}$ The leaves of this plant are used as spice having clove like taste and pepper like odor. ${ }^{5}$ Leaves of $C$. tamala (Tejpata) also yield an essential oil in distillation. The essential oil of the leaves is called 'Tejpata oil' which is medicinally used as carminative, antiflatulent, diuretic, and in cardiac disorders. ${ }^{6}$ Previously, various researchers reported its phytochemical and pharmacological values by using standard experimental methods. For example, leaves of this plant are effective in diabetic rats have antioxidants as well as have hypoglycemic anti-inflammatory and immunomodulation properties..$^{7-10}$ Recent studies shows that the leaf extracts 
of the plant have antidiabetic and antioxidant activities in streptozotocin (stz) treated diabetic rats and the bark was reported to have anti-diabetic activity by using $\alpha$-amylase inhibition assay. ${ }^{11,12}$ The present study focuses on the antidiabetic activities of the leaf extracts of $C$. tamala which are usually used in South-Asian cooking and sample was collected locally.

\section{METHODS}

C. tamala was collected from Tangail district in the central region of Bangladesh during January 2017. It was identified by Bangladesh national Herbarium Center (Acc. No. 43405) and the voucher specimen was deposited to the herbarium center Bangladesh. This study was undertaken in the laboratory of Biotechnology and Genetic Engineering Department, Mawlana Bhashani Science and Technology University, Santosh, Tangail, Bangladesh.

\section{Preparation of plant extract}

Leaves of $C$. tamala were extracted separately with $1.5 \mathrm{~L}$ of water by the method of continuous hot extraction at $60^{\circ} \mathrm{C}$ for $6 \mathrm{~h}$ and evaporated. These were designated as CTLEt. The residual extract was dissolved in water and used in the study.

\section{Animals}

Male albino rats (180-200gm body weight) were obtained and purchased from the Pharmacy Department of Jahangir Nagar University, Savar, Bangladesh, and were used for the determination of an abnormal high concentration of glucose in blood. Before using the rats for experiment, they could acclimatize to the laboratory condition for a week at a constant temperature of $22^{\circ} \mathrm{C}\left( \pm 5^{\circ} \mathrm{C}\right)$ with a relative humidity of $40-70 \%$ along with the natural 12 hours daynight cycle, in the laboratory of Biotechnology and Genetic Engineering Department, Mawlana Bhashani Science and Technology University, Santosh, Tangail Bangladesh. All described procedures were reviewed and approved by the Mawlana Bhashani Science and Technology University Animals Ethical Committee.

\section{Drugs and chemicals}

All drugs and biochemical components used in this experiment were purchased from the different research laboratories in Dhaka region, Bangladesh and the chemicals were of analytical grade.

\section{Preparation of C. tamala leaf solvent extraction}

Firstly, 10gm of air dried C. tamala leaf powder was placed in a conical flask containing $100 \mathrm{ml}(95 \%)$ ethanol and was plugged with cotton. Then it was shaken for several times to form a fine mixture of solution. After proper shaking it was filtered through a filter paper and then was centrifuged for 15 minutes. Then Supernatant was collected and evaporated to make final volume which is actually one-fourth of the original volume. Finally the mixture was stored at $4^{\circ} \mathrm{C}$ in air tight test tubes.

\section{Experimental design}

In the experiment, Animals were divided into four groups consisting of a minimum of three rats each. There were total 12 rats, including 9 diabetic surviving rats and 3 normal rats. Here, Group I was normal rats, Group II was Diabetes induced but non-treated with standard drug and C. tamala leaf extracts, Group III received treatment of $C$. tamala leaf extract in different amount of $1.0 \mathrm{ml}, 1.5 \mathrm{ml}$ and $2.0 \mathrm{ml}$ with lab diet and the Last group serves as a positive control received the standard drug (glibenclamide) at the dose of $5 \mathrm{mg} / 10 \mathrm{ml} \mathrm{WFI} / \mathrm{kg}$ of body weight. Before starting an experiment, the rats were weighed and carefully marked on the tail, right front, right back, left front, left back, and unmark which was later used as an identification mark for a particular rat before and after the drug administration which could be noted separately.

\section{Preparation of the solutions and reagents}

\section{Alloxan}

Alloxan monohydrate $\left(\mathrm{C}_{4} \mathrm{H}_{2} \mathrm{~N}_{2} \mathrm{O}_{4} \cdot \mathrm{H}_{2} \mathrm{O}\right)$ was available in colored bottles containing $25 \mathrm{gm}$ powder. The solution was prepared by dissolving $55 \mathrm{mg}$ in $5 \mathrm{ml}$ of WFI per $\mathrm{kg}$ of rat's body weight. The average weight of my grouped rats was $200 \mathrm{gm}$. That's why each rat has been injected $1 \mathrm{ml}$ of prepared Alloxan solution.

\section{Experimental induction of diabetes}

Normally, Animals are allowed to fast for $12 \mathrm{hr}$ and when they are administered with freshly prepared Alloxan monohydrate $150 \mathrm{mg} / \mathrm{kg}$ body weight intravenously but in this experiment, we used $55 \mathrm{mg} / 10 \mathrm{ml} \mathrm{WFI} / \mathrm{kg}$ body weight. ${ }^{13}$ This dose permanently destroys the beta cells of pancreas and produces diabetes mellitus. Blood glucose levels of all surviving rats were determined after 4 days of injecting Alloxan monohydrate. Rats with fasting serum glucose level more than $7 \mathrm{mmol} / \mathrm{L}$ were considered diabetic and were selected for further study.

\section{Dose and route of administration}

For the evaluation of hypoglycemic activity, $C$. tamala leaf extracts were provided with lab diet at a dose of daily $1 \mathrm{ml}$ for rat-1, $1.5 \mathrm{ml}$ for rat- 2 and $2.0 \mathrm{ml}$ for rat-3 for 18 hours. For all the pharmacological studies the drug glibenclamide was provided as a drug control at a dose of $5 \mathrm{mg} / 10 \mathrm{ml} / \mathrm{kg}$ body weight.

\section{Measurement of blood glucose concentration}

Blood samples were collected on the initial days for 4 weeks by amputation of the tail tip under diethyl ether anesthesia. Just before cutting the tail was immersed into warm water $\left(40^{\circ} \mathrm{C}\right)$ for approximately 22 seconds for 
vasodilatation. The level of blood glucose was determined initially and then continuously for 4 weeks. After cutting the tail tip $0.2 \mathrm{ml}$ blood was taken cautiously and the blood glucose level was measured by Glucometer (Glucoleader Enhance, HMD biomedical, Taiwan) using blood glucose test strip (FIA biomed, Germany) as per the supplied manufacturers protocol).

\section{RESULTS}

The present study evaluates the anti-hyperglycemic activity of $C$. tamala leaf extract (CTLEt) on blood glucose of Alloxan-induced male albino diabetic rats. Alloxaninduced hyperglycemia has been described as a useful experimental model to study the activity of hypoglycemic agents. Alloxan destroys beta-cells of the pancreas and induces hyperglycemia. In the study, experimental rats were divided into four Groups. Group I - Non diabetic control (only treated with laboratory diet), Group II Diabetic Control (Alloxan-induced and treated with laboratory diet) and Group III -Diabetic rats administered with $C$. tamala leaf extract (CTLEt) in doses of $1 \mathrm{ml}, 1.5$ $\mathrm{ml}$ and $2.0 \mathrm{ml}$ and Group IV- Diabetic rats administered with Glibenclamide at a dose of $2.5 \mathrm{mg} / 10 \mathrm{ml}$.

\section{Measurement of the blood glucose levels}

Firstly the blood glucose levels of all rats were measured in fasting conditions. In this experiment, blood glucose levels of all Albino rats were measured by Glucometer. The blood glucose levels of Group-I (Normal control) were treated with normal laboratory diet. Blood glucose levels of all rats in Group-I (Normal control) was normal. Group-II (diabetic control) rats were Alloxan induced and treated with normal laboratory diet and blood glucose levels were $7.0 \mathrm{mmol} / \mathrm{L}$ which meant those rats were in diabetic conditions. All rats of Group-III were treated with different doses of $C$. tamala leaf extracts. The blood glucose levels of all the rats in Group-IV (Medicine + lab diet) according to a disciplined way from fasting conditions then in every two hours of regular intervals up to eighteen hours all the readings were recorded. Fasting blood glucose (FBG) levels of each rat was taken every two hours of interval. More significant $(p<.05)$ antihyperglycemic activity was observed after eighteen hours of feeding in chronic Alloxan induced type-II diabetic model Albino rats. Table 1 shows group-I (Normal Control) mean blood glucose levels were increased to $18.81 \%$ which was considered a normal condition for normal rats and for group-IV (Medicine + lab diet) mean glucose levels decreased to $55.31 \%$ which was good. On the other hand for group-III (Diabetic rat + Leaf extract + lab diet) the mean glucose level was decreased to $58.04 \%$ which was higher than medicine and proved that $C$. tamala leaf extract worked against hyperglycemic activity and converted into hypoglycemic condition. These levels of reduction were much higher than medicine treated rats except $1.0 \mathrm{ml}$ solution of sample induction. We found $2.0 \mathrm{ml}$ solution of sample most effective. Table 2 shows the comparison of four groups in SE value. Values were statistically significant at $\mathrm{p}<0.01$ as compared with diabetic control. Figure 1 shows that after two hours of feeding glucose levels were gradually increased. For group-I (normal control) mean glucose level was normal but due to induction of Alloxan group-II (diabetic control), group-III (CTLEt + lab diet), group-IV (medicine + lab diet) mean glucose levels were higher than group-I (normal control). Fasting blood glucose (FBG) levels of each rat was taken every two hours of interval. More significant $(p<0.05)$ anti-hyperglycemic activity was observed after eighteen hours of feeding in chronic Alloxan induced type-II diabetic model Albino rats.

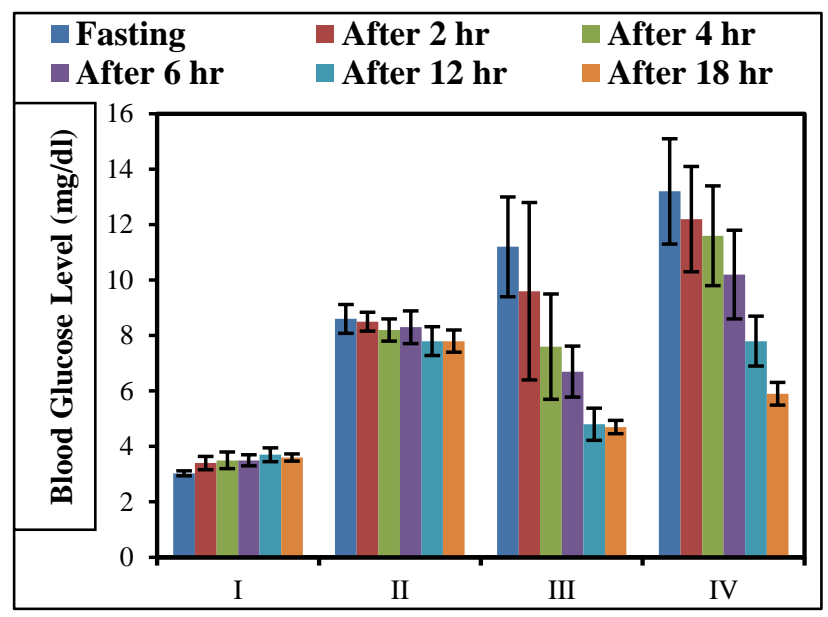

Figure 1: Blood glucose levels in different groups of treated rats.

Table 1: Comparisons among four groups with percentage (mean \pm percentage).

\begin{tabular}{|c|c|c|c|c|c|c|}
\hline Groups & $\begin{array}{l}\text { Fasting } \\
\text { mean } \\
\text { glucose level }\end{array}$ & $\begin{array}{l}\text { After } 2 \text { hours } \\
\text { mean glucose } \\
\text { level }\end{array}$ & $\begin{array}{l}\text { After } 4 \text { hours } \\
\text { mean glucose } \\
\text { level }\end{array}$ & $\begin{array}{l}\text { After } 6 \\
\text { hours mean } \\
\text { glucose level }\end{array}$ & $\begin{array}{l}\text { After } 12 \\
\text { hours mean } \\
\text { glucose level }\end{array}$ & $\begin{array}{l}\text { After } 18 \\
\text { hours mean } \\
\text { glucose level }\end{array}$ \\
\hline $\begin{array}{l}\text { Group-I (Normal } \\
\text { Control) }\end{array}$ & $\begin{array}{l}3.03 \\
(100 \%)\end{array}$ & $\begin{array}{l}3.4 \\
(112.21 \%)\end{array}$ & $\begin{array}{l}3.5 \\
(115.51 \%)\end{array}$ & $\begin{array}{l}3.5 \\
(115.51 \%)\end{array}$ & $\begin{array}{l}3.7 \\
(122.11 \%)\end{array}$ & $\begin{array}{l}3.6 \\
(118.81 \%)\end{array}$ \\
\hline $\begin{array}{l}\text { Group-II } \\
\text { (Diabetic Control) }\end{array}$ & $\begin{array}{l}8.6 \\
(100 \%)\end{array}$ & $\begin{array}{l}8.5 \\
(98.83 \%)\end{array}$ & $\begin{array}{l}8.2 \\
(94.16 \%)\end{array}$ & $\begin{array}{l}8.3 \\
(96.51 \%)\end{array}$ & $\begin{array}{l}7.8 \\
(90.69 \%)\end{array}$ & $\begin{array}{l}7.8 \\
(90.69 \%)\end{array}$ \\
\hline $\begin{array}{l}\text { Group-III (CTLEt } \\
\text { treated Control) }\end{array}$ & $\begin{array}{l}11.2 \\
(100 \%)\end{array}$ & $\begin{array}{l}9.6 \\
(85.71 \%)\end{array}$ & $\begin{array}{l}7.6 \\
(67.85 \%)\end{array}$ & $\begin{array}{l}6.7 \\
(59.82 \%)\end{array}$ & $\begin{array}{l}4.8 \\
(42.86 \%)\end{array}$ & $\begin{array}{l}4.7 \\
(41.96 \%)\end{array}$ \\
\hline $\begin{array}{l}\text { Group-IV } \\
\text { (Medicine control) }\end{array}$ & $\begin{array}{l}13.2 \\
(100 \%)\end{array}$ & $\begin{array}{l}12.2 \\
(92.42 \%)\end{array}$ & $\begin{array}{l}11.6 \\
(87.12 \%)\end{array}$ & $\begin{array}{l}10.2 \\
(77.27 \%)\end{array}$ & $\begin{array}{l}7.8 \\
(59.09 \%)\end{array}$ & $\begin{array}{l}5.9 \\
(44.69 \%)\end{array}$ \\
\hline
\end{tabular}


Table 2: Comparisons among four groups (mean $\pm \mathrm{SE})$.

\begin{tabular}{|lllllll|}
\hline Groups & $\begin{array}{l}\text { Fasting } \\
\text { mean } \\
\text { glucose level }\end{array}$ & $\begin{array}{l}\text { After 2 hours } \\
\text { mean glucose } \\
\text { level }\end{array}$ & $\begin{array}{l}\text { After 4 hours } \\
\text { mean glucose } \\
\text { level }\end{array}$ & $\begin{array}{l}\text { After 6 } \\
\text { hours mean } \\
\text { glucose level }\end{array}$ & $\begin{array}{l}\text { After 12 } \\
\text { hours mean } \\
\text { glucose level }\end{array}$ & $\begin{array}{l}\text { After 18 } \\
\text { hours mean } \\
\text { glucose level }\end{array}$ \\
\hline $\begin{array}{l}\text { Group-I (Normal } \\
\text { Control) }\end{array}$ & $3.03 \pm 0.09$ & $3.4 \pm 0.24$ & $3.5 \pm 0.30$ & $3.5 \pm 0.21$ & $3.7 \pm 0.25$ & $3.6 \pm 0.13$ \\
\hline $\begin{array}{l}\text { Group-II } \\
\text { (Diabetic Control) }\end{array}$ & $8.6 \pm 0.52$ & $8.5 \pm 0.34$ & $8.2 \pm 0.41$ & $8.3 \pm 0.61$ & $7.8 \pm 0.52$ & $7.8 \pm 0.40$ \\
\hline $\begin{array}{l}\text { Group-III (CTLEt } \\
\text { treated Control) }\end{array}$ & $11.2 \pm 1.8$ & $9.6 \pm 3.2$ & $7.6 \pm 1.9$ & $6.7 \pm 0.92$ & $4.8 \pm 0.58$ & $4.7 \pm 0.24$ \\
\hline $\begin{array}{l}\text { Group-IV } \\
\text { (Medicine control) }\end{array}$ & $13.2 \pm 1.9$ & $12.2 \pm 1.9$ & $11.6 \pm 1.8$ & $10.2 \pm 0.16$ & $7.8 \pm 0.91$ & $5.9 \pm 0.41$ \\
\hline
\end{tabular}

Each value represents mean; $\pm=\mathrm{SE} ; \mathrm{CT}=$ Cinnamomum tamala leaf extracts, Values were statistically significant at $\mathrm{p}<0.01$ as compared with diabetic control, $\mathrm{p}<0.01$ as compared with normal.

Table 3: Comparison between blood glucose level for the Cinnamomum tamala leaf extract treated Group III and Medicine Treated Control Group IV).

\begin{tabular}{|c|c|c|c|c|c|c|c|}
\hline No of Sample & Groups & Fasting condition & After 2 h & After $4 \mathrm{~h}$ & After 6 h & After $12 \mathrm{~h}$ & After $18 \mathrm{~h}$ \\
\hline \multirow{2}{*}{$\begin{array}{l}\text { Rat-1 (1.0ml of } \\
\text { CTLEt and lab diet) }\end{array}$} & G-III & 8.6 & 7.3 & 5.9 & 6.8 & 5.9 & 5.1 \\
\hline & G-IV & 13.9 & 13.4 & 12.9 & 11.5 & 8.1 & 6.5 \\
\hline \multirow{2}{*}{$\begin{array}{l}\text { Rat-2 }(1.5 \mathrm{ml} \text { of } \\
\text { CTLEt and lab diet })\end{array}$} & G-III & 10.4 & 5.6 & 5.4 & 5.1 & 3.9 & 4.9 \\
\hline & G-IV & 16.3 & 14.9 & 13.8 & 12.1 & 9.2 & 6.1 \\
\hline \multirow{2}{*}{$\begin{array}{l}\text { Rat-3 }(2.0 \mathrm{ml} \text { of } \\
\text { CTLEt and lab diet })\end{array}$} & G-III & 14.7 & 16.1 & 11.6 & 8.3 & 4.7 & 4.3 \\
\hline & G-IV & 9.3 & 8.4 & 8 & 7.1 & 6.2 & 5.1 \\
\hline
\end{tabular}

Table 3 shows that administration of Cinnamomum tamala leaf extract (CTLEt) and the Medicine treated on the diabetic induced rats, it was lowered the blood glucose level. Administration of the increasing dosage $1.0 \mathrm{ml}$, $1.5 \mathrm{ml}$ and $2.0 \mathrm{ml}$ of Cinnamomum tamala leaf extracts produced dose-dependent significant reductions in the blood glucose level of alloxan induced rats after 2 hours, 4 hours, 12 hours and 18 hours of treatment.

\section{DISCUSSION}

Results of the present study partially support the findings of and significant increase in body weight after treatment with herbal preparations in hyperglycemic animals. ${ }^{14,15}$ Similar results were reported after oral administration of the methanol fraction of Salacia reticulata twice daily to the diabetic animals which gained body weight. ${ }^{16}$ It is now established that there is a gradual decrease in beta-cell function and that may increase the risk of developing typeII diabetes. ${ }^{17-19}$ In this study we investigated the use of Cinnamomum tamala as antidiabetic agent. Alloxaninduced hyperglycemia has been a useful experimental model to study the activity of hypoglycemic agents. ${ }^{20}$

Alloxan was used to induce diabetes because it is known to cause degranulation to the beta cells of the pancreas. In our study three doses $(1.0 \mathrm{ml}, 1.5 \mathrm{ml}, 2.0 \mathrm{ml})$ of the ethanolic extract of $C$. tamala leaf and Glibenclamide drug did not show any significant changes in the fasting blood glucose levels when compared to untreated control after 2 h of treatment. However, after 4, 6, 8, 12 and 18 hours of treatments the extract showed a significant $(\mathrm{P}<0.5)$ decrease in the fasting blood glucose level when compared to untreated control and $2.0 \mathrm{ml}$ dose was found to be more effective in the glycemic change than the $1.0 \mathrm{ml}$ and $1.5 \mathrm{ml}$ doses. This shows that the extract does exhibit dose dependent activity.

The extract at a dose of $2.0 \mathrm{ml}$ showed a gradual reduction of the fasting blood glucose level $2 \mathrm{~h}$ after the administration of the extract.

The result of this present study indicated that Cinnamomum tamala leaf extract significantly reduce the blood sugar level in alloxan diabetic rats. The ethanol extract exhibited significant anti-hyperglycemic effect without causing hypoglycemia.

\section{CONCLUSION}

In conclusion, it may be stated that our observations are suggestive of the fact that the ethanol extract of C. tamala leaves possess antidiabetic activity in normal and diabetic male albino rats and can be improve the oral glucose tolerance (OGT) test by promoting the peripheral utilization of glucose and increasing the muscle glycogen store probably induced by stimulating insulin release from $\beta$-cells or through its insulin like action. The results are quite promising and demands further investigation. 


\section{ACKNOWLEDGEMENTS}

The authors are greatly thankful to the Department of Biotechnology and Genetic Engineering, Mawlana Bhashani Science and Technology University, Tangail, Bangladesh for the logistic supports.

Funding: No funding sources

Conflict of interest: None declared

Ethical approval: The study was approved by the Institutional Ethics Committee

\section{REFERENCES}

1. Jali MV, Kambar S, Jali SM, Gowda S. Familial early onset of type-2 diabetes mellitus and its complications. North American J of Med Sci. 2009;1:377-80.

2. Prabhakar PK, Doble M. Mechanism of action of natural products used in the treatment of diabetes mellitus. Chinese J of Int Med. 2011;17(8):563-74.

3. Uddin NS. Traditional Uses of Ethnomedicinal Plants of the Chittagong Hill Tracts. Bangladesh National Herbarium, Dhaka; 2006:446.

4. Ghani A. Medicinal Plants of Bangladesh. 1st ed. The Asiatic Society of Bangladesh, Dhaka, Bangladesh; 1998:164.

5. Hussain A, Virmani OP, Popil SP, Mishra LN, Gupta AK. Dictionary of Indian Medicinal Plants, CIMAP Lucknow, 1980.

6. Showkat RM, Mohammed A, Kapoor R. Chemical composition of essential oil of Cinnamomum tamala Nees and Eberm. leaves. Flavour and Fragrance Journal. 2004;19:112-4.

7. Bisht S, Sisodia SS. Assessment of antidiabetic potential of Cinnamomum tamala leaves extract in streptozotocin induced diabetic rats. Indian $\mathbf{J}$ of Pha. 2011;43:582-5.

8. Padmakumari Amma KP, Rani MP, Sasidharan I, Sreekumar MM. Comparative chemical composition and in vitroantioxidant activities of essential oil isolated from the leaves of Cinnamomum tamala and Pimenta dioica. Natural Product Research. 2013;27:290-4.

9. Kar A, Choudhary BK, Bandyopadhyay NG. Comparative evaluation of hypoglycaemic activity of some Indian medicinal plants in alloxan diabetic rats. J Ethnopharmacol. 2003;84:105-8.

10. Gupta R, Agnihotri PK, Johri S, Saxena AM. Hypoglycaemic activity of ethanol extract of Cinnamomum tamala leaves in normal and streptozotocin diabetic rats. Iran J Pharmacol Ther. 2009;8:17-21.
11. Kumanan R, Manimaran S, Saleemulla K, Dhanabal SP, Nanjan MJ. Screening of bark of Cinnamomum tamala (Lauraceae) by using $\alpha$-amylase inhibition assay for anti-diabetic activity. Int J Pharm Biomed Res. 2010;1:45-8.

12. Chakraborty U, Das H. Antidiabetic and antioxidant activities of Cinnamomum tamala leaf extracts in stz-treated diabetic rats. Glob J Biotech Biochem. 2010;5:12-8.

13. Akhtar, MS. Athar MA, Yaqub M. Effect of Momordica charantia on blood glucose level of normal and alloxan diabetic rabbits. Journal of Planta Med. 1985;42:205-10.

14. Ponnachan PTC, Paulose CS, Panikkar KR. Effect of leaf extract of Aegle marmelose in diabetic rats. Ind J Exp Biol 1993;31:345-7.

15. Perez CE, Domimguez JM, Romero RA, Campillo JE, Torres MD. A study on the glycaemic balance in streptozotocin-diabetic rats treated with an aqueous extract of Ficus carica (fig tree) leaves. Phytother. Res. 1998;10:82-3.

16. Kumara RNKVM, Pathirana RN, Pathirana C. Hypoglycemic activity of theroot and stem of Salacia reticulatavar. Beta-diandrain alloxan diabetic rats. Pharma. Biol. 2005;43:219-25.

17. Shibly AZ, Zohora FT, Islam Md S, Islam Md R. A comprehensive review on ethno pharmacological antidiabetic potential of traditional ayurvedic plants of Bangladesh. J of Pharmacognosy and Phytochemistry. 2015;4(1):107-12.

18. Palanisamy P, Srinath KR, Chowdary. Evaluation of Anti-oxidant and Anti-diabetic activities of Cinnamomum tamala Linn leaves in Streptozotocin induced diabetic rats. Int. Research $\mathrm{J}$ of Phar. 2011;2(12):157-62.

19. Patel DK, Kumar R, Laloo D, Hemalatha S. Diabetes mellitus: an overview on its pharmacological aspects and reported medicinal plants having antidiabetic activity. Asian Pacific J of Tro Bio. 2012;2(5):411-20.

20. Nammi S, Boini MK, Lodagala SD, Behara RB. The juice of fresh leaves of Catharanthus roseus Linn reduces blood glucose in normal and alloxan diabetic rabbits. BMC Complement Altern Medicine. 2003;2:3-4.

Cite this article as: Shibly AZ, Suborna LA, Adhikari J, Islam MS. Evaluation of antihyperglycemic activities of Bangladeshi medicinal plant Cinnamomum tamala Leaf extracts in alloxan treated Albino Rats. Int J Basic Clin Pharmacol 2018;7:11-5. 